\title{
A new angiosperm from the Crato Formation (Araripe Basin, Brazil) and comments on the Early Cretaceous Monocotyledons
}

\author{
FLAVIANA J. DE LIMA ${ }^{1}$, ANTÔNIO A.F. SARAIVA ${ }^{2}$, MARIA A.P. DA SILVA ${ }^{3}$, \\ RENAN A.M. BANTIM ${ }^{1}$ and JULIANA M. SAYÃ ${ }^{4}$ \\ ${ }^{1}$ Programa de Pós-Graduação em Geociências, Centro de Tecnologia e Geociências, \\ Universidade Federal de Pernambuco, Av. Acadêmico Hélio Ramos, s/n, Cidade Universitária, 50740-530 Recife, PE, Brasil \\ ${ }^{2}$ Laboratório de Paleontologia, Universidade Regional do Cariri, Rua Carolino Sucupira, s/n, 63100-000 Crato, CE, Brasil \\ ${ }^{3}$ Laboratório de Botânica Aplicada, Universidade Regional do Cariri, Rua Carolino Sucupira, s/n, 63100-000 Crato, CE, Brasil \\ ${ }^{4}$ Laboratório de Biodiversidade do Nordeste, Universidade Federal de Pernambuco, \\ Rua do Alto Reservatório, s/n, Bela Vista, 55608-680 Vitória de Santo Antão, PE, Brasil
}

Manuscript received on July 1, 2014; accepted for publication on September 9, 2014

\begin{abstract}
The Crato Formation paleoflora is one of the few equatorial floras of the Early Cretaceous. It is diverse, with many angiosperms, especially representatives of the clades magnoliids, monocotyledons and eudicots, which confirms the assumption that angiosperm diversity during the last part of the Early Cretaceous was reasonably high. The morphology of a new fossil monocot is studied and compared to all other Smilacaceae genus, especially in the venation. Cratosmilax jacksoni gen. et sp. nov. can be related to the Smilacaceae family, becoming the oldest record of the family so far. Cratosmilax jacksoni is a single mesophilic leaf with entire margins, ovate shape, with acute apex and base, four venation orders and main acrodromous veins. It is the first terrestrial monocot described for the Crato Formation, monocots were previously described for the same formation, and are considered aquatics. Cratosmilax jacksoni is the first fossil record of Smilacaceae in Brazil, and the oldest record of this family.
\end{abstract}

Key words: Araripe Basin, Cratosmilax jacksoni, Cretaceous, fossil leaf, Gondwana, Monocots.

\section{INTRODUCTION}

Leaves are the most visible organs of the plants, composing the majority of the fossil plants records (Wilf 1997, Mohr and Friis 2000, Friis et al. 2011). However, fossil leaves, especially angiosperms, are notoriously difficult to identify and are frequently found isolated as impressions or compressions (Crane et al. 1990, Wilf 2008). Several studies of Cretaceous fossil leaves, including analysies of vein patterns and histology, have brought useful information regarding the

Correspondence to: Flaviana Jorge de Lima

E-mail: flavianajorge@gmail.com systematic relationships of angiosperms and have contributed significantly to a better understanding of the evolution of early angiosperms (Hickey and Doyle 1977, Upchurch 1984, Upchurch and Dilcher 1990, Friis et al. 2006).

The size, form and venation pattern of fossil leaves are commonly preserved. Additional organic materials, such as cuticular remains, are less frequent and occasionally are also present (Upchurch and Dilcher 1990, Wilf 2008). In the Early Cretaceous, most of these records this record came from three deposits: Potomac Group - United States (Doyle and Hickey 1976, Hickey and Doyle 1977, 
Upchurch 1984), the Crato Formation - Brazil (Mohr and Friis 2000, Mohr and Eklund 2003, Mohr et al. 2006, 2007, Coiffard et al. 2013), and the Yixian Formation - China (Cao et al. 1998, Wu 1999, Leng and Friis 200w6). The record of fossil leaves is useful for evolutionary studies, such as floral characteristics (Hickey and Taylor 1991). Several authors used foliar venation for taxonomic purposes and/or species characterization in the description of angiosperms (Melville 1969, Rieger and Fournier 1982, Gerber and Les 1994, Carpenter et al. 2005, Nagalingum 2007).

The Smilacaceae leaves are atypical when compared to the general pattern shown by monocots - leaves with parallel veins - because they exhibit reticulate venation among the acrodromous main veins (Inamdar et al. 1983). Smilacaceae is intimately related to Liliaceae and sometimes included in this family (Barradas and Figueiredo 1974). Most botanists, however, treat Smilacaceae as a distinct family (Hutchinson 1973, Cronquist 1981, Dahlgren et al. 1985, Conran 1989), traditionally containing three genera: Ripogonum Forst and Forst, Heterosmilax Kunth and Smilax L. (Koyama 1960, Hutchinson 1973, Mabberley 1997, Takhtajan 1997, Conran 1998, Cameron and $\mathrm{Fu}$ 2000). Recently, only the Heterosmilax and Smilax have been attributed to Smilacaceae, being the Ripogonum genus dismembered and placed in another family, the Ripogonaceae (Conran and Clifford 1985). The Smilacaceae family usually has a climbing habit, petiolate leaves and reticulate venation, with the type genus Smilax (Inamdar et al. 1983, Conran 1989) occurring worldwide at tropical and subtropical regions of Africa, Americas, Eurasia and Oceania (Andreatta 1980).

This paper describes a new genus and specie of the angiosperms, a monocotyledon from the Crato Formation (Araripe Basin). The paleoflora of the Crato Formation is one of the few equatorial floras from the Early Cretaceous, it is diverse with many angiosperms, especially representatives of the clades magnoliids, monocotyledons and eudicots (Friis et al. 2011).

\section{GEOLOGICAL SETTING}

The Araripe Basin is located in the Northeast region of Brazil, at the central part of the Borborema province (Almeida and Hasui 1984) (Fig. 1). It is an intracratonic basin and the most extensive interior basin of the region (Mabesoone et al. 1994). Because of that, the stratigraphy of the Araripe Basin is very complex and controversial, and it has been through subsequent changes for further detailing (e.g. Beurlen 1962, 1971, Mabesoone and Tinoco 1973, Assine 2007, Brito-Neves 1990, Ponte and Appi 1990, Ponte and Ponte-Filho 1996, Neumann and Cabrera 1999, Viana and Neumann 2002, Valença et al. 2003, Martill 2007a, Kellner et al. 2013). The stratigraphic proposal by Neumann and Cabrera (1999), who carried out a detailed stratigraphic review of the Araripe Basin, raising the Santana Formation to group and Crato, Ipubi and Romualdo members to formations, is used here.

The Crato Formation is positioned at the bottom of the Santana Group, it is about $5.500 \mathrm{~km}^{2}$ of total area (Viana and Neumann 2002). It consists mainly of micritic laminated gray and cream limestones with halite pseudomorphs (Neumann et al. 2003). The Crato Formation (lacustrine-carbonatic) along with the upper part of the underlying Barbalha Formation (deltaic) constitutes the lacustrine aptianalbian sequence of the post rift phase of the Araripe Basin (Neumann et al. 2002, 2003). The fossiliferous record of this formation is abundant and diverse (Mabesoone and Tinoco 1973). The fossils are found in laminated limestones of lacustrine environment, developed under tropical, arid and semi-arid climatic conditions, with long intervals of dry weather and periodic precipitation (Neumann et al. 2003). The fossil content of Crato Formation includes an immense variety of fauna and flora, which contains plant fragments (Crane and Maisey 1991, Mohr and Friis 2000, Bernardes-de-Oliveira et al. 2003, Lima 
et al. 2012), insects (Martins-Neto 2001), ostracods (Berthou et al. 1994), conchostracans (Carvalho and Viana 1993), fishes (e.g. Santos 1947, CastroLeal and Brito 2004), amphibians (e.g. Kellner and Campos 1986, Baez et al. 2009), pterosaurs (Frey and Martill 1994, Sayão and Kellner 2000, 2006, Frey et al. 2003, Kellner and Campos 2007, Witton 2008, Pinheiro et al. 2011), crocodylomorphs (Salisbury et al. 2003, Figueiredo and Kellner 2009) and feathers (e.g. Sayão et al. 2011). The preservation of fossils is often excellent, conferring to the Crato Formation the status of Lagerstätte (Martill and Frey 1998, Kellner and Campos 1999, Sayão and Kellner 2000, Martill 2007a, b), more recently considered as a Konservat Lagerstätte (Selden and Nudds 2005).
The specimen MPSC PL 2400 was collected in an outcrop corresponding to the levels of laminated limestone of the Crato Formation, specifically in the quarry "Mina Idemar", city of Nova Olinda, Ceará (24M - 0423025E / UTM 9212692N). The specimen was collected at the C6-level carbonate, according to the proposal of Neumann and Cabrera (1999) (Fig. 1 D). The majority of the species and specimens of fossil plants, described for the Araripe Basin, do not not have any stratigraphic and geographic locations. These fossils are often deposited at scattered collections in museums and universities around the world. MPSC PL 2400 is the first fossil plant with precise stratigraphic and geographic location described for the Crato Formation.

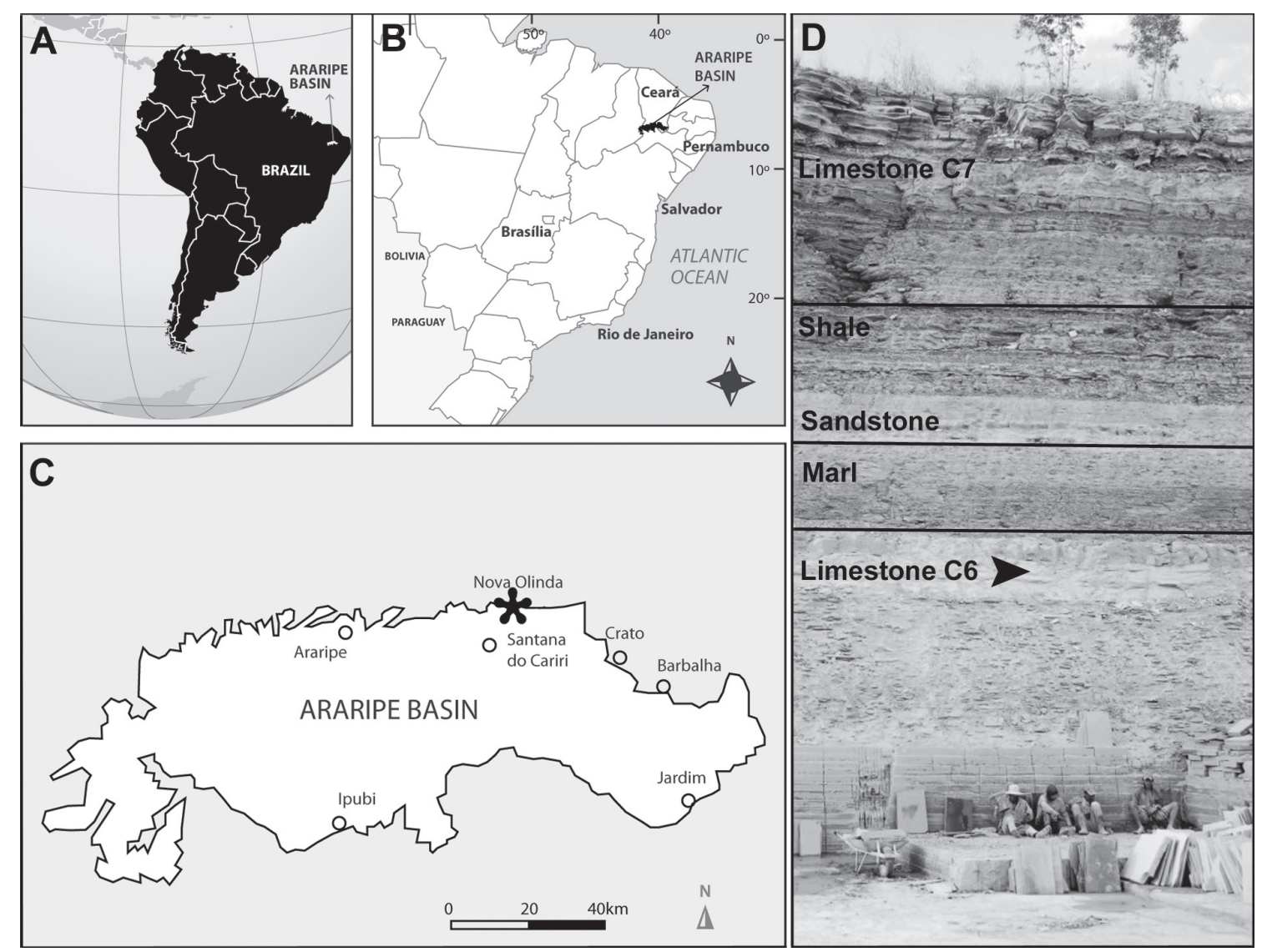

Figure 1 - A. Location of Araripe Basin in South America. B. The Araripe Basin bordering the states of Ceará, Piauí and Pernambuco in northeastern Brazil. C. Outline of the Araripe Plateau, indicating the approximate location of the quarry called "Mina Idemar" in Nova Olinda city, Ceará. D. Crato Formation layering at "Mina Idemar", indicating the laminated limestone C6-level (according to Neumann and Cabrera 1999) where the specimen was collected. Map modified from Sayão et al. 2011. 
ANGIOSPERMS FROM THE CRATO FORMATION

The paleoflora of the Crato Formation comprises representatives of ferns, gymnosperms and angiosperms, with a gymnosperm predominance (Lima 1978, Lima et al. 2012). Palynological and macrofloral data reveal a great variety of ferns and seed plants (Lima 1989, Mohr and Bernardes-de-Oliveira 2004, Batten 2007, Mohr et al. 2007, Heimhofer and Hochuli 2010). It is one of the few floras of North Gondwana which has continuously been studied for many years and thus provides a relatively detailed overview of the composition and diversity of the flora in this paleoequatorial area (Friis et al. 2011). Overall, approximately 35 taxa are recognized, including several gimnosperms and angiosperms (see Lima et al. 2012, for a review). The paleogeographic location is extremely important within the Arid Equatorial Floristic Province (Vakhrameev 1984, Meyen 1987), possibly because it is where the dispersion of the earliest angiosperms occurred (Mohr and Friis 2000, Bernardes-de-Oliveira et al. 2003).

The angiosperms represent the most wellknown and best described paleoflora record of the Crato Formation, standing out from the global fossiliferous record due to the preservation of flowering structures connected to vegetative parts (Friis et al. 2011). The angiosperm macrofossils are diverse and preserved as impressions, sometimes with entire plants containing roots, stems, leaves and reproductive structures in organic connection, although generally occurring as isolated leaves (Mohr and Friis 2000, Mohr and Rydin 2002, Mohr and Eklund 2003, Mohr and Bernardes-deOliveira 2004, Mohr et al. 2006, 2007). A variety of angiosperm foliar types have already been described, demonstrating moderate paleoequatorial diversity during the Lower Cretaceous (Mohr and Friis 2000). Examples of simple leaf morphotypes were reported for the Crato Formation and include whole leaves, from elliptic to obovate, pinnate and brochidodromous venation (Mohr and Friis 2000,
Mohr and Eklund 2003, Mohr and Bernardes-deOliveira 2004, Mohr et al. 2013).

In the Crato Formation many specimens have been previously referenced to the basal angiosperm (magnoliids), representing the majority of the plant record. However, only two taxa have been formally described; the members of the Magnoliales Endressinia brasiliana Mohr and Bernardes-de-Oliveira 2004 and Schenkeriphyllum glanduliferum Mohr, Coiffard and Bernardes-deOliveira 2013. E. brasiliana is the most ancient fossil described of the flora magnolialeana, which confirms the age of Magnoliales, previously inferred only by dispersed pollen (Mohr and Bernardes-de-Oliveira 2004). E. brasiliana consists of a branching axis with simple ovate leaves closely linked and several small terminal flowers. The $S$. glanduliferum is composed of simple, sessile and branched axes with mediumsized, tightly ovate leaves containing glands and solitary-axillary flowers. Several flowering structures of $S$. glanduliferum are reasonably well preserved in different stages of maturity.

Records of the eudicotyledon are scarce, composed only by Araripia florifera Mohr and Eklund 2003. This specie is preserved with leaves and flowers connected to a stalk. The combination of characteristics shared with several members of the Laurales, makes A. florifera a possible extinct representative of this order (Mohr and Eklund 2003).

Some angiosperms were described as having aquatic habit, commonly occurring in the Crato Formation. Klitzschophyllites flabellatus Mohr and Rydin 2002 has affinity to monocots, and the species is known from articulated branches with flabelate leaves, serrated margin, with possibly secreting glands salts. Pluricarpellatia peltata Mohr, Bernardes-de-Oliveira and Taylor 2008 is probably related to a basal lineage of Nymphaeales, and consists of plants with flowers with petiolate leaves ovate, peltate and elliptical. Iara iguassu Fanton, Ricardi-Branco, Dilcher 
and Bernardes-de-Oliveira 2006 supposedly a lineage of aquatic plants with flowers, not related to monocots or existent eudicotyledonous. It has stems with verticils of slender branches and may represent an extinct member. Jaguariba wiersemaniana Coiffard, Mohr and Bernardes-deOliveira 2013 is a member of Nymphaeaceae and presents a morphology clearly adapted to aquatic environments. The leaves of $J$. wiersemaniana are simple, petiolate, stemming and start directly from a rhizome. Spixiarum kipea Coiffard, Mohr and Bernardes-de-Oliveira 2013 belongs to the Araceae, is a monocot with roots highly branched and laterally thin with petiolate leaves.

\section{MATERIALS AND METHODS}

The holotype of Cratosmilax jacksoni gen. et sp. nov. is deposited in the Museu de Paleontologia of the Universidade Regional do Cariri, located at Santana do Cariri city under the number MPSC PL 2400. The leaves are preserved in abaxial face with the substitution of the organic matter by iron oxide. The specimen was mechanically prepared to show the parts of the fossil that were still covered by the sedimentary matrix (limestone), using the methodology proposed by Fairon-Demaret et al. (1999). Later, a fragment of the leaf surface was submitted to analysis on the Scanning Electron Microscope (SEM), but no microstructure was observed. The preservation of the fossil does not allow any detailed comparison of microstructures with other fossils or any systematic analysis of depth. Linear measurements were made with a digital caliper, and the angular (angle of the base, the apex, the emergence of secondary veins, etc.) with the protractor on implied photos. The surface measurements were calculated according to the formula (length $\mathrm{x}$ width $\mathrm{x}$ 0.75) suggested by the Manual of Leaf Architecture (Ellis et al. 2009) as a description of leaf architecture and terminology. The work of Conover (1983) was used for comparison and taxonomic identification. The distribution maps were made based on information from paleobiology database.

\section{RESULTS}

Systematic PALEONTOLOGY

Division Magnoliophyta Cronquist 1981

Class Monocotyledoneae Cronquist 1981

Order Liliales Perleb 1826

Family Smilacaceae Ventenat 1799

Cratosmilax gen. et

TYPE SPECIES

Cratosmilax jacksoni sp. nov.

ETYMOLOGY

Generic name "Cratosmilax" (= smilax of the Crato Formation $)=$ Crato derives from Crato Formation, geological formation of the Araripe Basin where important species of angiosperms were found, and smilax $=$ due to its similarity with the genus Smilax, a Smilacaceae up to now known only from the Holocene.

DIAGNOSIS

Same as type species

Cratosmilax jacksoni sp. nov. (Fig. 2)

TYPE SPECIMEN

Holotype MPSC PL 2400 deposited at the Museu de Paleontologia of the Universidade Regional do Cariri, Santana do Cariri - Ceará.

TYPE LOCALITY

Quarry "Mina Idemar", Nova Olinda city, Ceará. Stratigraphic unit: Crato Formation, Santana Group, Araripe Basin. Age: Lower Cretaceous (Aptian-Albian).

ETYMOLOGY

The specific epithet "jacksoni" is named after the geologist Francisco Jackson Antero de Sousa, professor and environmentalist. Defensor of the Araripe Basin natural patrimony. 

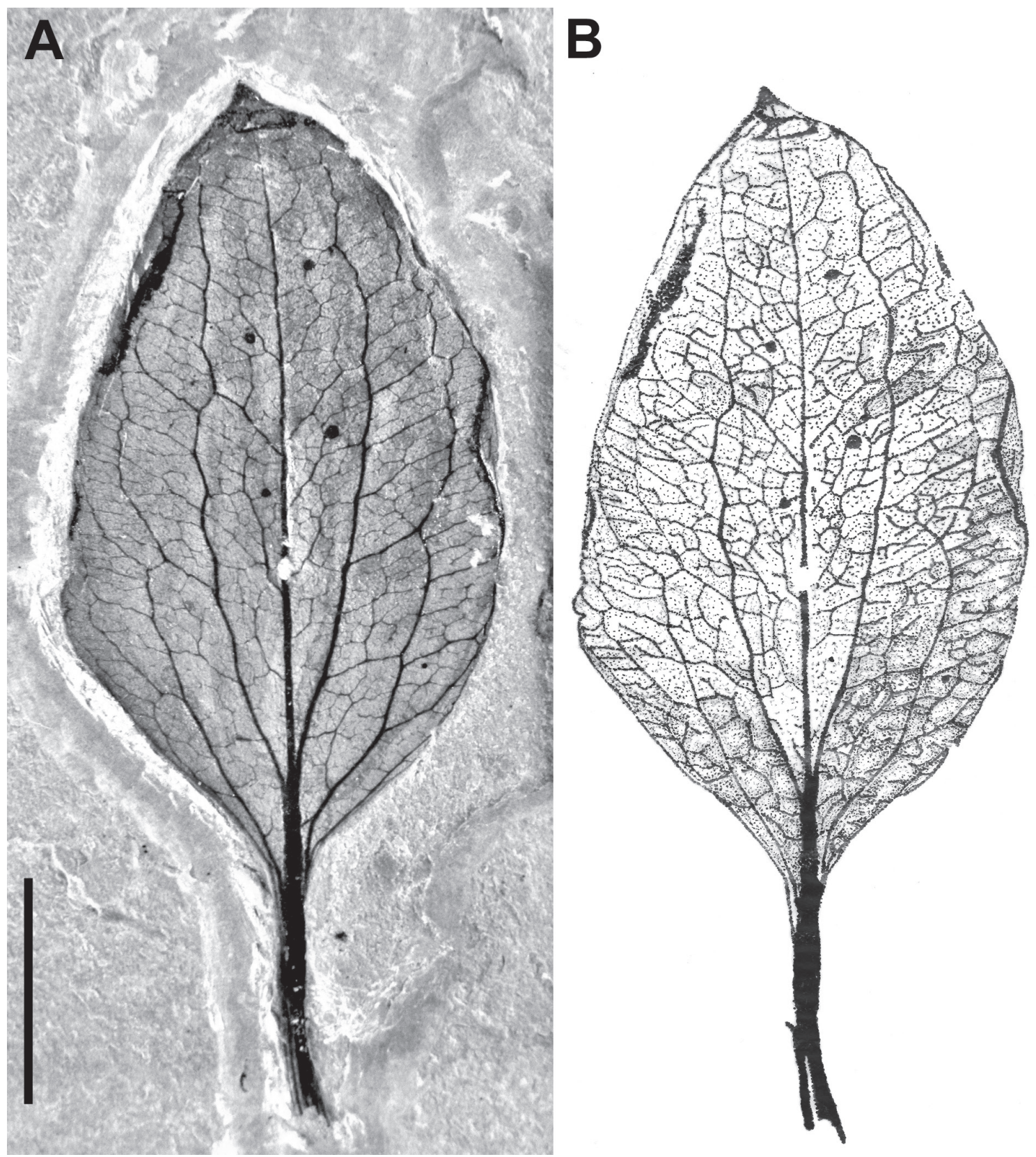

Figure 2 - Cratosmilax jacksoni gen. et sp. nov. A. Holotype, specimen MPSC PL 2400. B. Drawing of the Holopyte emphasizing the venation pattern. Scale bar $=150 \mathrm{~mm}$.

\section{DiAGNOSIS}

Simple leaf, ovate, with acute apex, attenuate base and entire margin, petiolated with channeled petiole finishing in a sheath. The main vein is prominent and straight. Two pairs of secondary veins run from the base of the lamina and end up on the upper portion being lost before reaching the apex, the secondary veins do not converge at the apex. The secondary veins are acrodromous and transverse veins are irregular. Thin quaternary veins, reticulate and orthogonal subparallel are present among the tertiaries forming an asymmetrical reticulate transversely disposed to the primary and secondary veins. 


\section{DESCRIPTION}

Cratosmilax jacksoni is composed of a single leaf with an entire margin (430 mm long by $240 \mathrm{~mm}$ wide) corresponding to a mesophyll leaf. The leaf is ovate, with the base $(210 \mathrm{~mm})$ wider than the apex $(15 \mathrm{~mm})$ and the center is $210 \mathrm{~mm}$ wide. The apex is acute in an angle of $70^{\circ}$ and the base is acute in an angle of $80^{\circ}$. The leaf has a long, channeled, striated petiole preserved with $150 \mathrm{~mm}$ long by $2 \mathrm{~mm}$ wide, ending in a sheath. The specimen shows four orders of venation, with suprabasal acrodromous secondary veins (Fig. 3). The primary vein is straight with $430 \mathrm{~mm}$ in length and is more prominent in the proximal portion of the limbo and thinner in the distal portion. There are two pairs of secondary veins in an opposite distichous way from the base of the lamina. Secondary veins emerge at a decurrent angle ranging from $5^{\circ}$ to $10^{\circ}$, parallel courses that do not converge at the apex, disappearing even before reaching the edge of the leaf. Left secondary veins converge at the apex with the main vein. Probably the secondary right vein would have reached the apex too, but the preservation of the specimen didnot allow this observation to be made.

The secondary veins are the acrodromous, forming an angle of $10^{\circ}$ at the base of the main vein. The first pair of secondary veins are 330$350 \mathrm{~mm}$ long and the second pair of secondary veins are 330-340 $\mathrm{mm}$ long. The angle between the main vein and the first pair of secondary veins is approximately $10^{\circ}$ and with the second pair is approximately $30^{\circ}$. Tertiary veins are quite evident and form an asymmetric transversal reticulate compared to primary and secondary veins ranging from $20 \mathrm{~mm}$ to $50 \mathrm{~mm}$. It shows quaternary fine veins, orthogonal subparallel reticulate between the tertiary, forming an asymmetrical reticulate transversely disposed to the primary and secondary veins. The angle between the main vein at the margin of the lamina is approximately $40^{\circ}$.
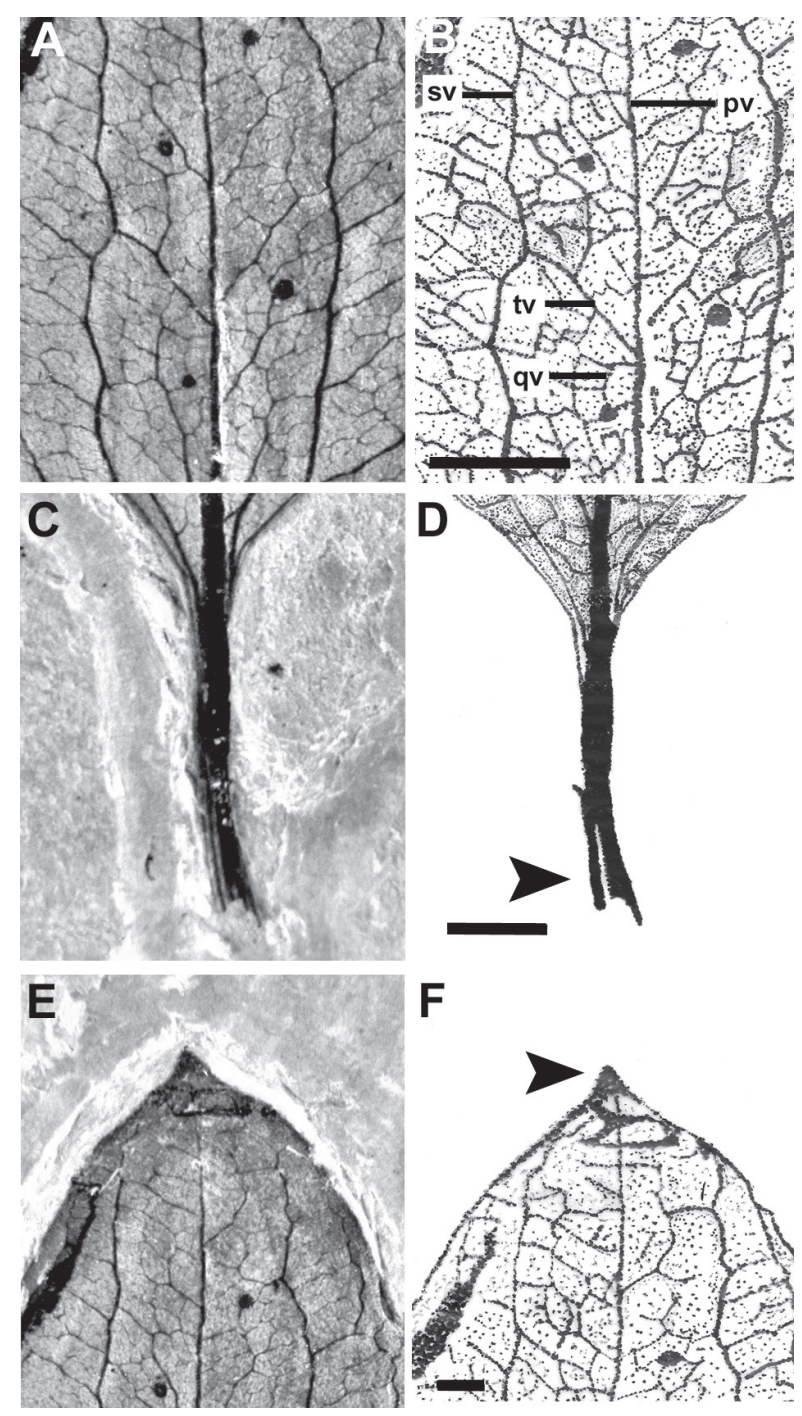

Figure 3 - A. Detail of venation of Cratosmilax jacksoni gen. et sp. nov. B. Drawing showing the presence four orders of venation: $\mathrm{pv}$ - primary vein; $\mathrm{sv}$ - secondary vein; $\mathrm{tv}$ - tertiary vein; qv - quaternary vein. C. The long petiole terminates in a sheath. D. Drawing showing details of the petiole. E. Acute foliar apex. F. Details of the acute apex forming an angle of $70^{\circ}$ in the drawing. Scale bars $=10 \mathrm{~mm}$ in A-B; $5 \mathrm{~mm}$ in C-D; $2 \mathrm{~mm}$ in $\mathbf{E}-\mathbf{F}$.

The leaf margin is folding in both midline and apex areas. This feature is observed in leaves that are in the process of resecting (Mader 1995). Probably the resecting occurred before the fossilization of Cratosmilax holotype. In taphonomic ways, the preservation of the whole leaf with delicate and acute apex indicates none or little transportation 
(Mohr et al. 2006). The iron oxide in the fossil, usually found in Crato Formation, can sometimes make them brittle and fragile.

\section{DISCUSSION}

The monocots have a long record in the fossil history, which began in the Early Cretaceous (Daghlian 1981, Herendeen and Crane 1995, Gandolfo et al. 2000, Bremer 2000). In the Upper Cretaceous it was expected that the monocot were both widespread and diverse (Herendeen and Crane 1995), however the fossil record has shown this group with mostly Laurasian distribution with the exception of a record in Brazil. Many orders of monocots are not fully represented during the Upper Cretaceous or consist only of scattered records (Friis et al. 2004). Nevertheless, the records of Cretaceous monocots are not common, when compared to the large amount of data on eudicotyledons of the same age (Doyle 1973, Daghlian 1981, Hotton et al. 1994, Herendeen and Crane 1995, Cox et al. 1995) (Fig. 4). The monocots usually occur more in the fossil palynoflora than in the macrofossil record (Hotton et al. 1994, Cox et al. 1995). Cratosmilax jacksoni reinforces the presence of monocots in the Early Cretaceous, as proposed before by the occurrence of Klitzschophyllites flabellatus and Spixiarum kipea (Doyle 1973, Walker and Walker 1984), not in accordance with Gandolfo et al. (2000), who statedthat the first fossils of monocotyledons were securely identified for the Turonian.
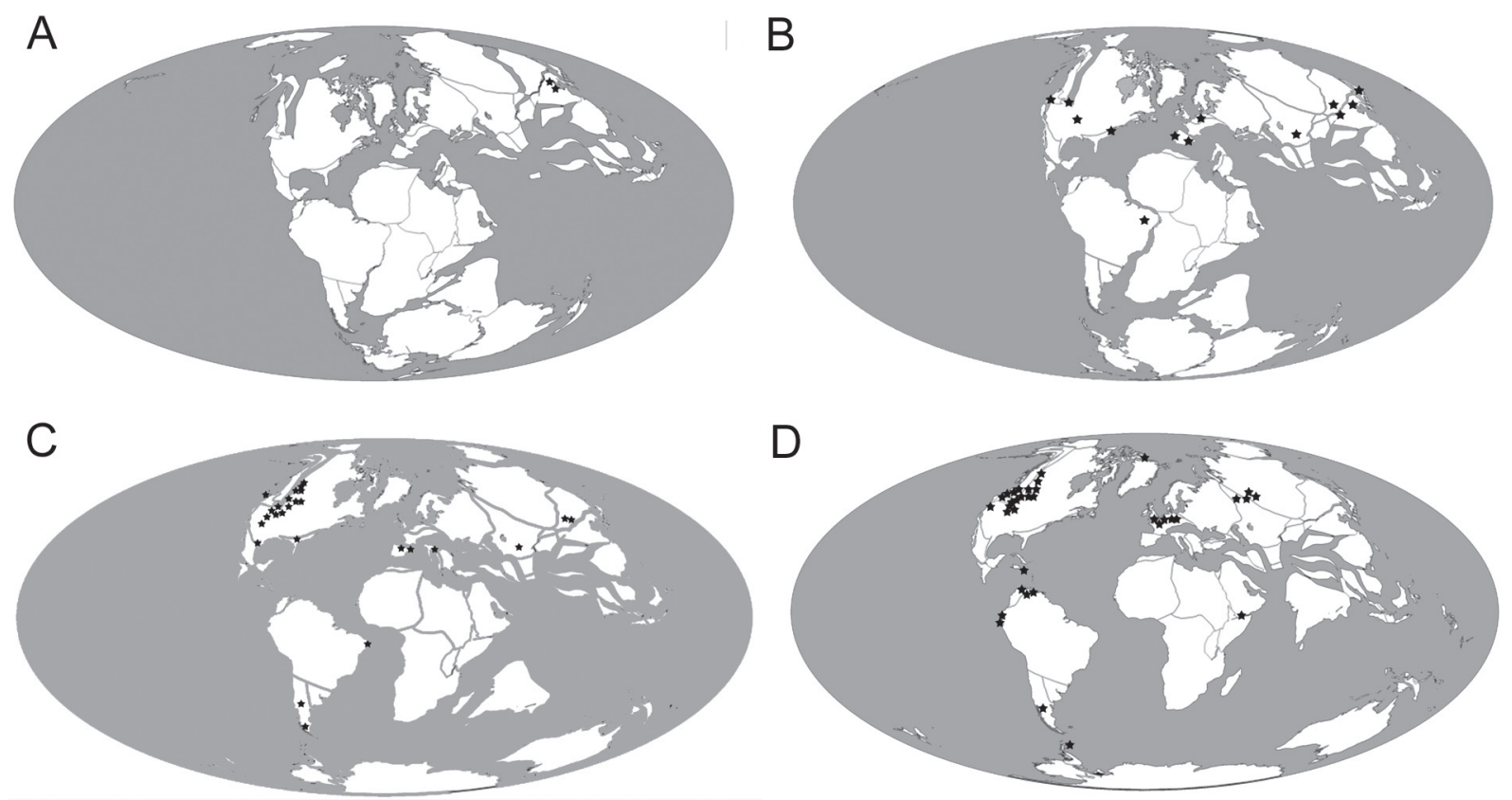

Figure 4 - Distribution map of angiosperms during Mesozoic and Cenozoic: A. First records at the Upper Jurassic. B. Early Cretaceous. C. Upper Cretaceous. D. Paleogene.

Previous works proposed parallel venation of the leaves as an apomorphy of the monocots (Doyle and Hickey 1976, Dahlgren et al. 1985, Borsch et al. 2003, Conran et al. 2009). However, this characteristic is absent in some Araceae, Dioscoreaceae, Smilacaceae and other members of this group (Dahlgren et al. 1985, Stevenson et al. 2000). Since some evidences support the idea that reticulate venation evolved secondarily in these taxa, parallel veins should be considered as plesiomorphic (Doyle and Endress 2000, Wilson and Morrison 2000). 
Most angiosperm synapormorphies are related to the reproductive system, but the vegetative parts, such as the leaves of most angiosperms, also possess a suite of features that are not seen in other plant groups (Friis et al. 2006). The main characteristics that differ angiosperms leaves from other groups is the presence of a hierarchical system of successive finer veins, veins with free termination and anastomosed between two or more orders, forming a reticulate venation pattern (Doyle 1973, Hickey and Wolfe 1975). Stipules are also considered typical of angiosperms, although not common among monocots (Friis et al. 2005). Similar to what occurs to pollen grains, the systematic determination of fossil leaves at lower levels is often complicated due to broad patterns of convergent evolution (Friis et al. 2005). In the past, many works had solely used leaves in their systematic determinations (Hickey and Doyle 1977, Upchurch 1984). With the discovering of new and more complete fossils, this kind of analysis became untrustworth. The only way to assert the taxonomic status of a leaf is by using the venation pattern (Hickey and Wolfe 1975) and the cuticular structures (Dilcher 1974). This has significantly improved the possibilities for useful comparative studies (e.g. Upchurch and Dilcher 1990). C. jacksoni is a narrow monocot leaf with several orders of venation after the primary and although it could exhibit stipule this has not been preserved. The ovate form, margin entire, veins acrodromous with reticulate venation of $C$. jacksoni are common architectural features in some recent monocot leaves, especially Liliales (Cronquist 1981, Dahlgren et al. 1985). Inside this order $C$. jacksoni shares reticulate venation with Dioscoreaceae (especially Dioscorea L.). However, the main leaf venation of Dioscorea is percurrent opposite alternate, where the tertiary veins cross the secondary adjacent, forming parallel paths with no branch (Conover 1991, Ding and Gilbert 2000, Raz 2002). This venation is different in C. jacksoni, which presents the tertiary veins crossing the secondary in a disorganized and opposite way, but forming a branch-shaped network. While there are similarities between $C$. jacksoni and Ripogonum (Ripogonaceae), the latter differs by having a blade leaf with a second pair of suprabasal lateral veins, acute to acuminate apex, without stipules. Furthemore, in many cases there is a well-developed drip tip (Conran and Clifford 1985, Conran 1989, 1998, Conran et al. 2009). C. jacksoni has no pairs of suprabasal lateral veins, and the drip tip is considerably shorter, these features, however, are not sufficient to include it in Ripogonaceae family.

According to the Angiosperm Phylogeny Group II system (APG II 2003), the Smilacaceae already contains Smilax and Heterosmilax (Ding et al. 2011). Usually the leaves of Heterosmilax blades have a broad form (large blade and petiole) ovate or lanceolate oblong, based cordate and entire or slightly lobed margin (Chen et al. 2000). C. jacksoni cannot be associated with Heterosmilax, since the basis, the number of major veins and the way the veins converge in the apex are distinct.

Cratosmilax shares some features with Smilax, especially regarding the venation which is typically reticulate acrodromous venation. Besides this characteristic, several species of the genus Smilax present an acute ovate blade to linear-lanceolate (Caponetti and Quimby 1956, Andreatta and Pereira 1990, Andreatta 1997, 2000, Guaglianone and Hurrell 2009). The Smilax species are variable in habit, leaf form, number of main veins, etc (Fig. 5). Some species show absolutely diagnostic features, but most are differentiated by a set of unremarkable details, closely relatable, not always easy to interpret (Andreatta 2000, Guaglianone and Gatusso 2006). The number of major veins (3-5-7) can be a useful characteristic in separating or grouping of species of Smilax (Barradas and Figueiredo 1974, Martins 2009), but the remarkable difference between Smilax and the Cratosmilax is that main veins do not converge completely at the apex. 


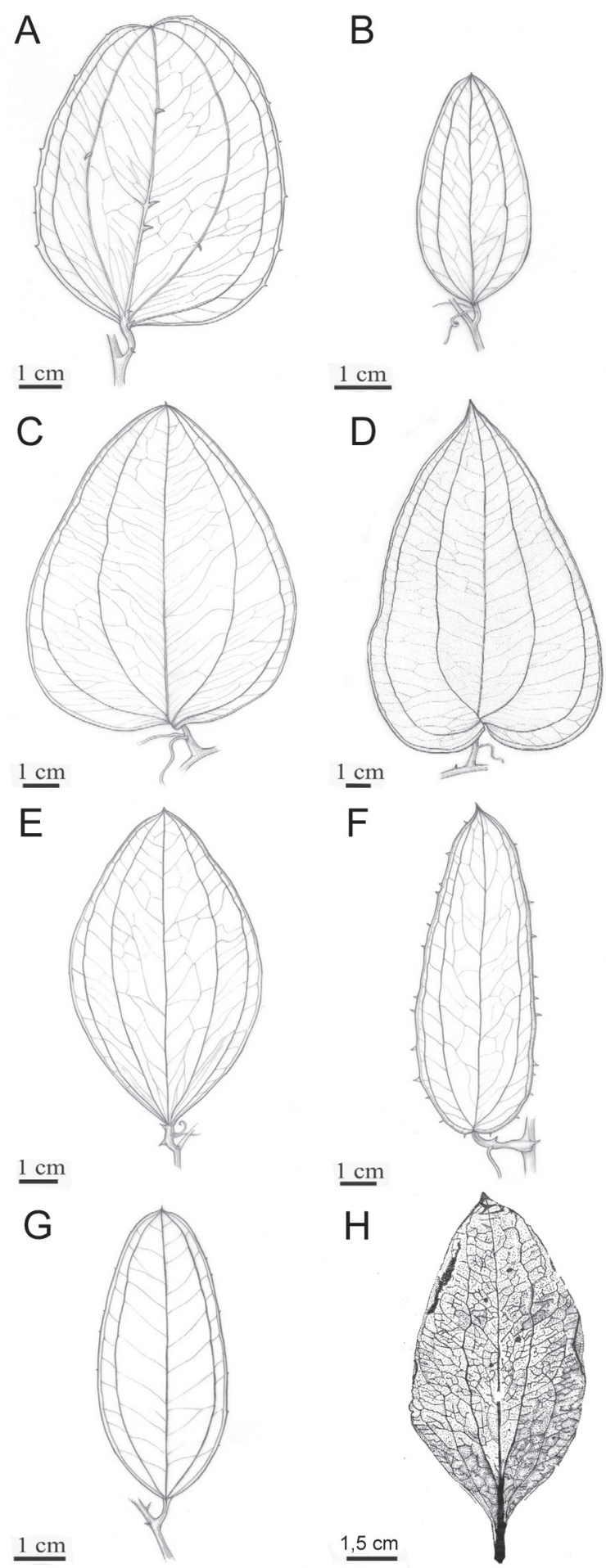

Figure 5 - Comparison among the external leaf morphologies of Cratosmilax jacksoni gen. et sp. nov and seven species of Smilax. A. Smilax brasiliensis. B. Smilax campestris. C. Smilax cissoids. D. Smilax fluminensis. E. Smilax goyazana. F. Smilax oblongifolia. G. Smilax rufescens. H. Cratosmilax jacksoni. From A to G after Martins et al. 2013
Several fossil species of Smilax were reported for different locations in the Upper Cretaceous, Eocene and Miocene (e.g. Berry 1929, Morita 1931, MacGinitie 1953, Sun and Dilcher 1988, Dilcher and Lott 2005, Macovei and Givulescu 2006, Erdei and Rákosi 2009) (Fig. 6). Reliable fossil records of Smilax occurred frequently throughout the Cenozoic northern hemisphere (Conran et al. 2009). Generally, fossil plants are identified based on the macrostructures of leaves, but some species with similar forms, as some Cenozoic angiosperms, are generally classified by their epidermal characteristics (Bainian et al. 2004). Up to now there is no record of Smilacaceae even in the Crato palynoflora, as well asnor in other deposits of Early Cretaceous age. The early record of pollen of such plants comes from the Upper Cretaceous of Antarctic Penynsula (Dutra 2004) and the Pachaco Formation in Argentina (Prámparo et al. 1996).

Two monocots have been recorded in the Crato Formation paleoflora: Klitzschophyllites flabellatus and Spixiarum kipea. The plant of aquatic habits $K$. flabellatus, has orbicular leaves attached to stems trifurcated with the main veins and venation flabellate longitudinally and transversely thinner between the large veins forming an array (Mohr and Rydin 2002, Doyle et al. 2008). In K. flabellatus the fine venation is typical of monocots, but the main venation, is ending in spines at the leaf margin (Mohr and Rydin 2002). Based on leaf characteristics of $K$. flabellatus it is noticeable that it differs completely from C. jacksoni. The second record of the Crato Formation monocot is $S$. kipea, a herbaceous plant with petiolate leaves, characterized by several orders of parallel acrodromous veins converging apically and finer transverse veins, the leaves are ovate with acute base (Coiffard et al. 2013). Although it has similarities with C. jacksoni the leaf architecture size, form and disposal of the veins are different. K. flabellatus and S. kipea are aquatic plants or adapted to live in water (Mohr and Rydin 2002, Coiffard et al. 2013), therefore, Cratosmilax 

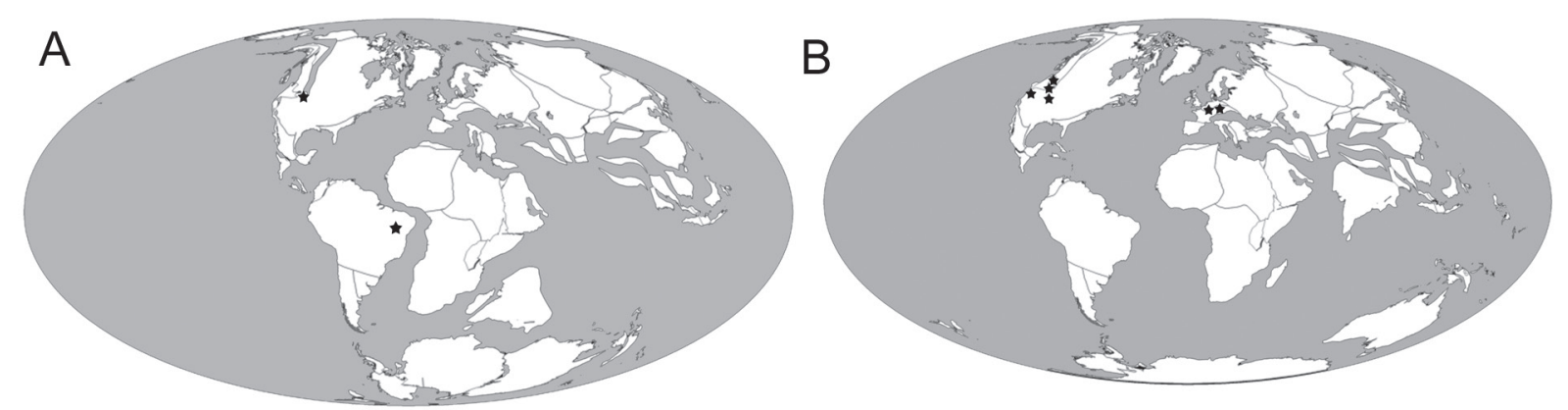

Figure 6 - First distribution patterns of Smilacaceae during Mesozoic and Cenozoic. A. In the Cretaceous, limited to Brazil and USA. B. In the Paleogene the records are limited, up to now to the Northern Hemisphere (USA and Europe).

jacksoni is the first monocot plant described with terrestrial habit for the Crato Formation.

Although dispersed fossil leaf no clear evidence about the systematic relationships of plants, they supply information on the level of complexity in leaf architecture. It may also, to some extent, be used to infer the paleoecology of the study area, height and habits of angiosperms, complexity and density of venation, which are key features in the leaf function (Boyce et al. 2009, Feild et al. 2011, Sack et al. 2012). The veins are considered one of the most visible traces of the leaves, which provide support, water distribution, carbohydrates exportation and are crucial for maintaining adequate amounts of water and amount and photosynthetic capacity (Sack and Holbrook 2006).

\section{CONCLUSION}

The unique architectural characteristics of the leaf presented by Cratosmilax jacksoni supports that this fossil corresponds to a new genus and species of Smilacaceae. Based on the leaf structure (presence of sheath) and venation pattern (reticulated acrodromous), Cratosmilax jacksoni is placed as monocot angiosperms. This taxon would be the first monocot plant with terrestrial habits described so far to the Crato Formation, only known before for aquatic plants Klitzschophyllites flabellatus and Spixiarum kipea. The description of this taxon brings new information to the Crato paleoflora, one of the few localities in the paleoequatorial region and, therefore, of great interest for climate reconstructions of the Early Cretaceous. Cratosmilax jacksoni represents the first fossil of Smilacaceae family in Brazil, composing the oldest record of this family of angiosperms so far.

\section{ACKNOWLEDGMENTS}

We thank the Conselho Nacional de Desenvolvimento Científico e Tecnológico (CNPq) for financial support to authors (F.J.L. \#142390/2013-5; J.M.S. \#401787/2010-9). We would also like to thank the Fundação Cearense de Apoio ao Desenvolvimento Científico e Tecnológico (FUNCAP) for the research in the region, as well as the Instituto Nacional de Paleontologia e Arqueologia do Semiárido (INAPAS). We are grateful to Dr. JA Doyle (University of California) and Dr. GR Upchurch (University-San Marcos) for the discussion about monocots fossils. We thank biologist MF Teixera for helping with collection at the quarries, A Pinheiro for the photographs and R Andrade for helping with the English version of the manuscript. The authors would also like to thank the anonymous reviewers for comments and sugestions that improved this paper.

\section{RESUMO}

A paleoflora da Formação Crato é uma das poucas floras equatoriais do Cretáceo Inferior. É diversificada, com 
muitas angiospermas, especialmente representantes dos clados magnoliids, monocotiledôneas e eudicotiledôneas, confirmando a hipótese de que a diversidade das angiospermas durante a última parte do Cretáceo Inferior era ralativamente alta. A morfologia de uma nova mocotiledônea fóssil é estudada e comparada com outros gêneros de Smilacaceae, especialmente a venação. Cratosmilax jacksoni n. gen. n. sp. pode ser relacionada com a família Smilacaceae, tornando-se o registro mais antigo da família, até então. Cratosmilax jacksoni consiste de uma única folha mesófila com margem inteira, ovada, com ápice e base agudos, quatro ordens de venação e veias principais acródromas. É a primeira monocotiledônea terrestre descrita para a Formação Crato, monocotiledôneas foram anteriormente descritas para a mesma formação, e são consideradas aquáticas. Cratosmilax jacksoni é o primeiro registro fóssil da família Smilacaceae no Brasil, e o registro mais antigo desta família.

Palavras-chave: Bacia do Araripe, Cratosmilaxjacksoni, Cretáceo, folha fóssil, Gondwana, Monocotiledôneas.

\section{REFERENCES}

Almeida FFM And Hasui Y. 1984. O Pré-Cambriano do Brasil. São Paulo: Edgard Blücher, 378 p.

ANDREATTA RHP. 1980. Smilax Linnaeus (Smilacaceae): ensaio para uma revisão das espécies brasileiras. Arq Jard Bot Rio J 24: 179-301.

ANDREATTA RHP. 1997. Revisão das espécies brasileiras do gênero Smilax Linnaeus (Smilacaceae). PesquisasBotânica 47: 7-244.

ANDREATTA RHP. 2000. Smilacaceae. In: DI MAIO FR AND SILVA MBR (Coord), Espécies ameaçadas de extinção no município do Rio de Janeiro: Flora e Fauna. Rio de Janeiro: Secretaria Municipal de Meio Ambiente, 68 p.

ANDREATTA RHP AND PEREIRA TS. 1990. Morfologia das plântulas de algumas espécies de Smilax L. PesquisasBotânica 41: 7-24.

Angiosperm Phylogeny Group. 2003. An update of the Angiosperm Phylogeny Group classification for the orders and families of flowering plants: APG II. Bot J Linn Soc 141: $399-436$

Assine ML. 2007. Bacia do Araripe. In: Boletim de Geociências. Petrobras, Rio de Janeiro 15(2): 371-389.

BAEz AM, Moura GJB AND BATTEN RG. 2009. Anurans from the Lower Cretaceous Crato Formation of northeastern Brazil: implications for the early divergence of neobatrachians. Cretaceous Res 30: 829-846.
Bainian S, Yan D, XIE S, CONG P, XIN C AND Yun F. 2004. Palaeogene fossil Populus leaves from Lanzhou Basin and their palaeoclimatic significance. Chinese Sci Bull 49(14): 1494-1501.

BARRADAS M AND Figueiredo R. 1974. Contribuição ao estudo da nervação foliar de plantas dos cerradosLiliaceae, subfamília Smilacoideae. Hoehnea 4: 1-11.

BATTEN DJ. 2007. Spores and pollen from the Crato Formation: biostratigraphic and palaeoenvironmental implications. In: MARTILL DM ET AL. (Eds), The Crato Fossil Beds of Brazil: Window into an Ancient World. Cambridge University Press, Cambridge, p. 566-73.

BERNARDES-DE-OliVEIRA MEC, DilChER D, BARRETO AMF, Branco FR, Mohr B AND Fernandes MCC. 2003. La Flora del Miembro Crato, Formación Santana, Cretácico Temprano de la Cuenca de Araripe, Noreste del Brasil. 10 Congreso Geológico Chileno, Concepción. Actas, p. s/n-s/n.

BERRY EW. 1929. The flora of the Frontier Formation. United States Geological Survey. Professional Paper 158: 129-135.

Berthou PY, DePeChe F, COLIN JP, FILGUeIRA JBM AND TELES MSL. 1994. New data on the ostracods from Crato lithologic units (lower member of the Santana Formation, Latest Aptian-Lower Albian) of the Araripe Basin (Northeastern Brazil). Acta Geol Leopol 39(2): 539-554.

BEURLEN K. 1962. Geologia da Chapada do Araripe. An Acad Bras Cienc 34: 365-370.

BEURLEN K. 1971. As condições ecológicas e faciológicas da Formação Santana na Chapada do Araripe (Nordeste do Brasil). An Acad Bras Cienc 43: 411-415.

Borsch T, Hilu KW, Quandt D, Wilde V, Neinhuis C AND BARTHLOTT W. 2003. Noncoding plastid trnT-trnF sequences reveal a well resolved phylogeny of basal angiosperms. J Evolution Biol 16: 558-576.

Boyce CK, BRodribB TJ, FIELD TS AND ZwEINIECKI MA. 2009. Angiosperm leaf vein evolution was physiologically and environmentally transformative. Proc R Soc B 276: 1771-1776.

BREMER K. 2000. Early Cretaceous lineages of monocot flowering plants. P Natl Acad Sci USA 97: 4707-4711.

Brito-NeVES BB. 1990. A Bacia do Araripe no contexto geotectônico regional. In: Simpósio sobre a Bacia do Araripe e Bacias Interiores do Nordeste, 1, Crato. Atas... Crato: DNPM/SBP/SBG, p. 21-33.

CAMERON KM AND FU CX. 2000. Untangling the catbriers: phylogenetic studies in Smilacaceae. Am J Bot 87(6): 117.

CaO Z, Wu S, Zhang P AND Li J. 1998. Discovery of fossil monocotyledons from Yixian Formation, western Liaoning. Chinese Sci Bull 43: 230-233.

CAPONETTI JD AND QUIMBY MW. 1956. The comparative anatomy of certain species of Smilax. Journal of the American Pharmaceutical Association 45: 691-696.

CARPENTER RJ, HiLl RS AND JORDAN G.J. 2005. Leaf cuticular morphology links Platanaceae and Proteaceae. Int J Plant Sci 166: 843-855.

CARVALHO IS AND VIANA MSS. 1993. Os conchostráceos da Bacia do Araripe. An Acad Bras Cienc 65: 181-188. 
CASTRO-LEAL ME AND BRITO PM. 2004. The ichthyodectiform Cladocyclus gardneri (Actinopterygii: Teleostei) from the Crato and Santana formations, Lower Cretaceous of Araripe Basin, north-eastern Brazil. Ann Palaontol 90: 103-113.

Chen SC, Koyama T And Liang SY. 2000. Smilax L. and Heterosmilax Kunth. In: WU ZY AND RAVEN PH (Eds), Flora of China, 24. St. Louis: Science Press, Beijing and Missouri Botanical Garden Press, p. 96-117.

COIFFARd C, MoHr BAR AND BERnARDES-DE-OliveIRA MEC. 2013. The Early Cretaceous Aroid, Spixiarum kipea gen. et sp. nov., and implications on early dispersal and ecology of basal monocots. Taxon 62(5): 997-1008.

CONOVER MV. 1983. The vegetative morphology of the reticulate-veined Liliiforae. Telopea 2: 401-412.

CONOVER MV. 1991. Epidermal patterns of the reticulateveined Liliiflorae and their parallel-veined allies. Bot $\mathrm{J}$ Linn Soc 107(3): 295-312.

CONRAN JG. 1989. Cladistic analyses of some net-veined Liliiflorae. Plant Syst Evol 168: 123-141.

CONRAN JG. 1998. Smilacaceae. In: KUBITZKI K (Ed). The Families and Genera of Vascular Plantas. 3, Flowering Plants, Monocotyledons, Lilianae (except Orchidaceae). Berlin: Springer-Verlag, p. 417-422.

CONRAN JG, CARPENTER RJ AND JORDAN GJ. 2009. Early Eocene Ripogonum (Liliales: Ripogonaceae) leaf macrofossils from southern Australia. Aust Syst Bot 22(3): 219-228.

CONRAN JG AND CLIFFORD HT. 1985. The taxonomic affinities of the genus Ripogonum. Nord J Bot 5: 215-219.

Cox PA, Huynh KL And Stone BC. 1995. Evolution and systematics of Pandanaceae. In: RUDALL PJ et al. (Eds), Monocotyledons: Systematics and Evolution. Royal Botanical Gardens, Kew, p. 663-684.

CRANE PR AND MAISEY JG. 1991. Fossil plants. In: MAISEY JG 1991 (Ed). Santana fossils: an illustrated atlas. T.F.H. Publications, Neptune City, NJ, USA, p. 414-419.

Crane PR, MANChester SR AND Dilcher DL. 1990. A preliminary survey of fossil leaves and well-preserved reproductive structures from the Sentinel Butte Formation (Paleocene) near Almont, North Dakota. Field Geol 20: 1-63.

CRONQUIST A. 1981. An Integrated System of the Classification of Flowering Plants. Columbia University Press, New York.

DAGHLIAN CP. 1981. A review of the fossil record of monocotyledons. Bot Rev 47: 517-555.

DAHLGRen RMT, ClifFord HT AND YeO PF. 1985. The families of monocotyledons. Berlin: Springer-Verlag, p. $1-520$.

DILCHER DL. 1974. Approaches to the identification of angiosperm leaf remains. Bot Rev 40: 1-157.

Dilcher DL AND LOTT TA. 2005. A middle Eocene fossil plant assemblage (Powers Clay Pit) from western Tennessee. Bulletin Florida Museum Natural History 45(1): 1-43.

DING ZD AND GILBERT MG. 2000. Dioscoreaceae. In: WU ZY AND RAVEN PH (Eds), Flora of China: Flagellariaceae through Marantaceae, 24. Beijing: Science Press, and Missouri Botanical Garden Press, St. Louis, p. 276-296.
DING ST, Sun B-N, WU JY AND LI X-C. 2011. Miocene Smilax leaves and associated epiphyllous fungi from Zhejiang, East China and their paleoecological implications. Rev Palaeobot Palyno 165: 209-223.

DOYLE JA. 1973. Fossil evidence on early evolution of the monocotyledons. Q Ver Biol 48: 399-413.

DOYLE JA AND ENDRESS PK. 2000. Morphological phylogenetic analysis of basal angiosperms: Comparison and combination with molecular data. Int J Plant Sci 161: 121-153.

DOYLE JA, ENDRESS PK AND UpCHURCH GR. 2008. Early Cretaceous monocots: a phylogenetic evaluation. Sborník Národního Muzea v Praze 64: 59-87.

Doyle JA AND Hickey LJ. 1976. Pollen and leaves from the mid-Cretaceous Potomac Group and their bearing on early angiosperm evolution. In: BECK CB (Ed). Origin and Early Evolution of Angiosperms. New York: Columbia University Press, p. 139-206.

DUTRA TL. 2004. Paleofloras da antártica e sua relação com os eventos tectônicos e paleoclimáticos nas altas latitudes do sul. Rev Bras Geoc 34(3): 401-410.

Ellis B, DALY DC, Hickey LJ, JOHNSON KR, Mitchell JD, WILF P AND WING SL. 2009. Manual of leaf architecture. New York: Cornell University Press; New York Botanical Garden.

ERdeI B. AND RÁKosi L. 2009. The Middle Eocene flora of Csordakút (N Hungary). Geol Carpath 60(1): 43-57.

FAIRON-DEMARET M, HiLton J AND BERRY CM. 1999. Surface preparation of macrofossils (dégagement). In: JONES TP AND ROWE NP (Eds), Fossil Plants and Spores: Modern Techniques. London: Geological Society, p. 33-35.

FANTON JCM, RICARDI-BRANCO F, DILCHER D AND BERNARDESDE-OLIVEIRA MEC. 2006. Iara iguassu, a new taxon of aquatic angiosperm from the Crato Palaeoflora (Lower Cretaceous, Santana Formation, Araripe Basin, Northeastern Brazil). Geociências 25(2): 211-216.

FEILD TS ET AL. 2011. Fossil evidence for Cretaceous escalation in angiosperm leaf vein evolution. Proc Natl Acad Sci 108: 8363-8366.

Figueiredo RG AND KeLlner AWA. 2009. A new crocodylomorph specimen from the Araripe Basin (Crato Member, Santana Formation), northeastern Brazil. Paläontol Z 83: 323-331.

Frey E AND MARTiLl DM. 1994. A new pterosaur from the Crato Formation (Lower Cretaceous, Aptian) of Brazil. N Jb Geol Paläont Abh 194: 379-412.

Frey E, MartiLl DM AND BuChy MC. 2003. A new crested ornithocheirid from the Lower Cretaceous of northeastern Brazil and the unusual death of an unusual pterosaur. In: BUFFETAUT E AND MAZIN JM (Eds), Evolution and Palaeobiology of Pterosaurs. London: Geol Soc, Spec Pub 217: 55-63.

FriIs EM, CRANE PR AND PEDERSEN KR. 2011. Early flowers and angiosperm evolution. Cambridge University Press, 585 p.

FriIs EM, PEDERSEN KR AND CRANE PR. 2004. Araceae from the Early Cretaceous of Portugal: Evidence on the emergence of monocotyledons. Proc Natl Acad Sci 101: $16565-16570$. 
FRIIS EM, PEDERSEN KR AND CRANE PR. 2005. When Earth started blooming: insights from the fossil record. Curr Opin Plant Biol 8: 1-8.

FriIs EM, PEDERSEN KR AND CRANE PR. 2006. Cretaceous angiosperm flowers: innovation and evolution in plant reproduction. Palaeogeogr Palaeocli Palaeoecol 232(6): 251-293.

GANDOLFO MA, NiXON KC AND CREPET WL. 2000. Monocotyledons: A review of their Early Cretaceous record. In: WILSON K AND MORRISON D (Eds), Proceedings of the Second International Conference on the Comparative Biology of the Monocotyledons. Sydney, Australia; CSIRO, p. 44-52.

GERBER DT AND LES DH. 1994. Comparison of leaf morphology among submersed species of Myriophyllum (Haloragaceae) from different habitats and geographical distributions. Am J Bot 81: 973-979.

GuAgLianone ER AND GATUSSO S. 2006. Smilacaceae. In: NOVARA LJ (Ed), Fl. Del Valle de Lerma (Salta, Argentina). Aportes Bot. Salta, ser. Flora 7(16): 1-6.

GuAglianONE ER AND HuRRell JA. 2009. Smilacaceae Flora Rioplatense. Sistemática, ecología y etnobotánica de las plantas vasculares rioplatenses. Parte 3 (Monocotiledóneas). 4, Buenos Aires, p. 391-400.

HeImHofer U AND Hochuli PA. 2010. Early Cretaceous angiosperm pollen from low-latitude succession (Araripe Basin, NE Brazil). Rev Palaeobot Palynol 161: 105-126.

HerendeEn PS AND CRANE PR. 1995. The fossil history of the monocotyledons. In: RUDALL PJ et al. (Eds), Monocotyledons: systematics and evolution. Kew: Royal Botanical Gardens, p. 1-21.

HICKEY LJ AND DOYLE JA. 1977. Early Cretaceous fossil evidence for angiosperm evolution. Bot Rev 43: 2-104.

HICKEY LJ AND TAYLOR DW. 1991. The leaf Architecture of ticodendron and the application of foliar characters in discerning its relationships. Ann Mo Bot Gard 78: 105-130.

HiCKEY LJ AND WOLFE JA. 1975. The bases of angiosperm phylogeny: vegetative morphology. Ann Mo Bot Gard 62: 538-589.

Hotton ClK, LefFingwell HA AND SkVARla J. 1994. Pollen ultrastructure of Pandanaceae and the fossil genus Pandaniidites. In: KURMANN MH AND DOYLE JA (Eds). Ultrastructure of Fossil Spores and Pollen. Its Bearing on Relationships among Fossil and Living Groups. Kew: The Royal Botanic Gardens, p. 173-91.

HutChinson J. 1973. The Families of Flowering Plants Arranged According to a New System Based on Their Probable Phylogeny, 3rd ed. Clarendon Press, Oxford, UK, p. 1-492.

INAMDAR JA, SHENOY KN AND RAO NV. 1983. Leaf architecture of some monocotyledons with reticulate venation. Ann Bot-London 52(5): 725-736.

Kellner AWA And CAMPos DA. 1986. Primeiro registro de Amphibia (Anuro) no Cretáceo Inferior da Bacia do Araripe, Nordeste do Brasil. An Acad Bras Cienc 58: 610.

KELLNER AWA AND CAMPOS DA. 1999. Vertebrate paleontology in Brazil - a review. Episodes 22(3): 238-251.
Kellner AWA AND CAMPOS DA. 2007. Short note on the ingroup relationships of the Tapejaridae (Pterosauria, Pterodactyloidea). Bol Museu Nacional 75: 1-14.

Kellner AWA, CAmpos DA, SAyão JM, SARAiva AAF, Rodrigues T, Oliveira G, Cruz LA, Costa FR, Silva H AND FERREIRA JS. 2013. The largest flying reptile from Gondwana: a new specimen of Tropeognathus cf. T. mesembrinus Wellnhofer, 1987 (Pterodactyloidea, Anhangueridae) and other large pterosaurs from the Romualdo Formation, Lower Cretaceous, Brazil. An Acad Bras Cienc 85: 113-135.

KOYAMA T. 1960. Materials toward a monograph of the genus Smilax. Q J Taiwan Mus 13(1-2): 1-61.

LENG Q AND FRIIS EM. 2006. Angiosperm leaves associated with Sinocarpus Leng et Friis infructescences from the Yixian Formation (mid-Early Cretaceous) of NE China. Plant Syst Evol 262: 173-87.

LIMA FJ, SARAIVA AAF AND SAYÃo JM. 2012. Revisão da Paleoflora das Formações Missão Velha, Crato e Romualdo, Bacia do Araripe, Nordeste do Brasil. Estudos Geológicos 22: 99-115.

LIMA MR. 1978. Palinologia da Formação Santana (Cretáceo do Nordeste do Brasil). Introdução geológica e descrição sistemática dos polens da subturma Azonotriletes. Ameghiniana 15: 333-365.

LIMA MR. 1989. Palinologia da Formação Santana (Cretáceo do Nordeste do Brasil). IV, Systematic description of pollen from plicate and porous pollen, spores, incertae sedis and marine microplankton. Ameghiniana 26: 63-81.

MABBerley DJ. 1997. The Plant-Book. A Portable Dictionary of the Higher Plants. Cambridge: Cambridge University Press.

Mabesoone JM And Tinoco IM. 1973. Palaeoecology of the Aptian Santana Formation (northeastern Brazil). Palaeogeogr Palaeocl Palaeoecol 14: 97-118.

MABesoone JM, Viana MSS AND Lima FiLho MF. 1994. Sedimentary fill of the Araripe-Potiguar depression (NE Brazil). Abstracts, 14th Intern. Sedim. Cong., Recife-Brazil. Universidade Federal de Pernambuco, Pernambuco, Brazil, p. 46-47.

MacGinitie HD. 1953. Fossil plants of the Florissant Beds, Colorado. Carnegie Institution of Washington Publication 559: 1-198.

Macovei GH AND Givulescu R. 2006. The presents stage in the knowledge of the fóssil at Chiuzbaia, Mramures, Romania. Carpathian J Earth Environ Sci 1(1):41-52.

MADER D. 1995. Thaphonomy, sedimentology and genesis of plant fossil deposit types in Lettenkohle (Lower Keuper) and Schilfsandstein (Middle Keuper) in Lower Franconia (Germany). Germany, Ed. Europäischer Verlag der Wissenschaften, $164 \mathrm{p}$.

MARTILL DM. 2007a. The age of the Cretaceous Santana Formation fossil Konservat Lagerstätte of northeast Brazil: a historical review and an appraisal of the biochronostratigraphic utility of its paleobiota. Cretaceous Res 28: 895-920. 
MARTILL DM. 2007b. The geology of the Crato Formation. In: MARTILL DM ET AL. (Eds), The Crato fossil beds of Brazil, window to an ancient world, Cambridge: University Press, p. 8-24.

MARTILL DM AND FREY E. 1998. A new pterosaur Lagerstätten in NE Brazil (Crato Formation, Aptian, Lower Cretaceous), Preliminary observations. Oryctos 1: 79-85.

MARTINS AR. 2009. Morfoanatomia, germinação e perfil químico de espécies de Smilax L. (Smilacaceae). Tese de Doutorado em Biologia Vegetal. Universidade Estadual de Campinas. 158 p.

Martins AR, Bombo AB, SoARes AN AND AppezzATo-DAGLÓRIA B. 2013. Aerial stem and leaf morphoanatomy of some species of Smilax. Rev. Bras. Farmacogn. Braz. J Pharmacogn 23(4) 576-584.

Martins-Neto RG. 2001. Primeiro registro de Trichoptera (Insecta) na Formação Santana (Cretáceo Inferior), Bacia do Araripe, nordeste do Brasil, com descrição de sete novos táxons. In: Simpósio sobre a Bacia do Araripe e Bacias Interiores do Nordeste, 1 e 2, Crato, 1990/1997. Boletim, p. 212-226.

MELVILLE R. 1969. Leaf venation patterns and the origin of the angiosperms. Nature 224: 121-125.

MEYEN SV. 1987. Fundamentals of palaeobotany. Chapman and Hall, London. 432 p.

Mohr BAR AND BernARdes-DE-OliveIRA MEC. 2004. Endressinia brasiliana, a Magnolialean angiosperm from the Lower Cretaceous Crato Formation (Brazil). Int J Plant Sci 165: 1121-1133.

MOHR BAR, BERNARDES-DE-OLIVEIRA MEC, BARALE G AND OUAJAM. 2006. Palaeogeographic distribution and ecology of Klitzschophyllites, and early Cretaceous angiosperm in Southern Laurasia and Northern Gondwana. Cretaceous Res 27: 464-472.

MOHR BAR, BERNARDES-DE-OLIVEIRA MEC AND LOVERIDGE RF. 2007. The macrophyte flora of the Crato Formation. In: MARTILL DM ET AL. (Eds), The Crato Fossil Beds of Brazil: Window into an Ancient World. Cambridge: Cambridge University Press, p. 537-565.

MOHR BAR, BERNARDES-DE-OLIVEIRA MEC AND TAYLOR DW. 2008. Pluricarpellatia, a nymphaealean angiosperm from the Lower Cretaceous of northern Gondwana (Crato Formation, Brazil). Taxon 57(4):1147-1158.

MOHR BAR, COIFFARD C AND BERNARDES-DE-OlIVEIRA MEC. 2013. Schenkeriphyllum glanduliferum, a new magnolialean angiosperm from the Early Cretaceous of Northern Gondwana and its relationships to fossil and modern Magnoliales. Rev Palaeobot Palynol 189: 57-72.

MoHr BAR AND EKLUND H. 2003. Araripia florifera, a magnoliid angiosperm from the lower Cretaceous Crato Formation (Brazil). Palaeobot Palynol 126: 279-292.

MOHR BAR AND FrIIS EM. 2000. Early angiosperms from the Aptian Crato Formation (Brazil), a preliminary report. Int J Plant Sci 161(6): 155-167.
MOHR BAR AND RYDIN C. 2002. Trifurcatia flabellata $\mathrm{n}$. gen. n. sp., a putative monocotyledon angiosperm from the Lower Cretaceous Crato Formation (Brazil). Geowissenschaftliche Reihe 5: 335-344.

Morita H. 1931. On New Species of the Genera Cimwmomum and Smilax from the Miocene deposits of Oguni-Machi. Uzen Province, Japan. Geol Geogr 4: 1-8.

NAGALINGUM NS. 2007. Marsileaceaephyllum, a new genus for marsileaceous macrofossils: Leaf remains from the Early Cretaceous (Albian) of southern Gondwana. Plant Syst Evol 264: 41-55.

NEUMANN VH, BorRego AG, CABRERA L AND Dino R. 2003. Organic matter composition and distribution through the Aptian-Albian lacustrine sequences of the Araripe Basin, northeastern Brazil. Int J Coal Geol 54: 21-40.

NEUMANN VH AND CABRERA L. 1999. Una nueva propuesta estratigrafica para la tectonosecuencia post-rifte de la cuenca de Araripe, noreste de Brasil. In: BOLETIM DO $5^{\circ}$ SIMPÓSIO SOBRE O CRETÁCEO DO BRASIL, São Paulo, p. 279-285.

Neumann VH, Cabrera L, Mabesoone JM, Valença LMM AND SILVA AL. 2002. Ambiente sedimentar e facies da seqüência lacustre aptiana-albiana da bacia do Araripe, NE do Brasil. In: $6^{\circ}$ Simpósio sobre o Cretáceo do Brasil e $2^{\circ}$ Simpósio sobre el Cretácico de América del Sur, Rio Claro. Anais... Rio Claro, UNESP, p. 37-51.

PERLEB L. 1826. Lehrbuch der Naturgeschichte des Pflanzenreichs. Druck und Verlag von Friedrich Wagner, 129 p.

Pinheiro FL, Fortier DC, Schultz CL, De ANDrade JAFG AND BANTIM RAM. 2011. New information on Tupandactylus imperator, with comments on the relationships of Tapejaridae (Pterosauria). Acta Palaeontol Pol 56(3): 567-580.

PonTE FC AND APPI CJ. 1990. Proposta de revisão da coluna litoestratigráfica da Bacia do Araripe. Congresso Brasileiro de Geologia, 36, Natal, p. 211-226.

Ponte FC AND PONTE-FILHO FC. 1996. Estrutura geológica e evolução tectônica da Bacia do Araripe. Departamento Nacional da Produção Mineral, Recife, 68 p.

PrÁMPARO MB, PAPÚ OH AND Milana JP. 1996. Estudio palinológico del Miembro Inferior de la Formación Pachaco, Terciario de la Provincia de San Juan, descripciones sistemáticas. Ameghiniana 33(4): 397-407.

RAZ L. 2002. Dioscoreaceae. In: FLORA OF NORTH AMERICA EDITORIAL COMMITTEE (Ed), Flora of North America, vol. 26. New York and Oxford: OxfordUniversity Press, p. 479-485.

RIEGER IMC AND FoURNIER LAO. 1982. Patrones de venacion en algunas lauraceas de costa rica. Brenesia 19(20): 451-464.

SACK L AND HolBrooK NM. 2006. Leaf hydraulics. Ann Rev Plant Biol 57: 361-381.

Sack L, Scoffoni C, Mckown AD, Frole K, Rawls M, HAVRAn JC, Tran H AND TRAN T. 2012. Developmentally based scaling of leaf venation architecture explains global ecological patterns. Nature Communications 3: 837. 
SAlisbury SW, Frey E, MARTILl DM AND BuChy MC. 2003. A new crocodilian from the Lower Cretaceous Crato Formation of northeastern Brazil. Palaeont Abt A 270: 3-47.

SANTOS RS. 1947. Uma redescrição de Dastilbe elongatus, com algumas considerações sobre o gênero Dastilbe. Divisão de Geologia e Mineralogia, Notas preliminares e Estudos 42: 1-7.

SAYÃO JM AND KELlner AWA. 2000. Description of a pterosaur rostrum from the Crato Member, Santana Formation (Aptian-Albian) northeastern Brazil. Bol Mus Nac 54: 1-8.

SAYÃo JM AND KELLNER AWA. 2006. Novo esqueleto parcial de pterossauros (Pterodactyloidea, Tapejaridae) do Membro Crato (Aptiano), Formação Santana, Bacia do Araripe, nordeste do Brasil. Estudos Geológicos 16: 16-40.

SAYÃo JM, SARAIVA AAF AND UEJIMA AMK. 2011. New evidence of feathers in the Crato Formation supporting a reappraisal on the presence of aves. An Acad Bras Cienc 83(1): 197-210.

SELDEN PA AND NUDDS JR. 2005. Evolution of Fossil Ecosystems. Manson Publishing, Ltd., 192 p.

STEVEnson DW, DAVIS JI, FreudensteIn JV, HARDy CR, Simmons MP AND SPECHT CD. 2000. A phylogenetic analysis of the monocotyledons based on morphological and molecular character sets, with comments on the placement of Acorus and Hydatellaceae. In: WILSON K AND MORRISON D (Eds), Monocots: Systematics and Evolution. Melbourne: CSIRO Publishing, p. 17-24.

SUN Z AND DILCHER DL. 1988. Fossil Smilax from Eocene sediments in western Tennessee. Am J Bot 75: 118.

TAKHTAJAN AL. 1997. Diversity and Classification of Flowering Plants. New York: Columbia University Press.

UPCHURCH GR. 1984. Cuticle evolution in Early Cretaceous angiosperms from the Potomac Group of Virginia and Maryland. Ann Mo Bot Gard 71: 522-550.
UPCHURCH GR AND DILCHER DL. 1990. Cenomanian angiosperm leaf megafossils, Dakota Formation, Rose Creek Locality, Jefferson County, southeastern Nebraska. US Geol Surv Bulletin 1915: 1-55.

VAKHRAMEEV VA. 1984. Floras and chmates of the Earth in the Early Cretaceous epoch. Sov Geol 1: 4-49.

VALENÇA LMM, NEUMANN VH AND MABESOONE JM. 2003. An overview on Calloviane Cenomanian intracratonic basins of northeast Brazil: onshore stratigraphic record of the opening of the southern Atlantic. Geol Acta 1:261-275.

Ventenat EP. 1799. Pyrenaceae. "Tableau du Régne Végétal". Imprimerie de J. Drisonier: Paris 2: 315-324.

VianA MSS AND NeUMANN VHL. 2002. Membro Crato da Formação Santana, Chapada do Araripe, CE. Riquíssimo registro de fauna e flora do Cretáceo. In: SCHOBBENHAUS C et al. (Eds). Sítios Geológicos e Paleontológicos do Brasil. Brasília: DNPM/CPRM/ SIGEP, p. 113-120.

WALKER JW AND WALKER AG. 1984. Ultrastructure of Lower Cretaceous angiosperm pollen and the origin and early evolution of flowering plants. Ann Mo Bot Gard 71: 464-521.

WILF P. 1997. When are leaves good thermometers? A new case for leaf margin analysis. Paleobiology 23: 373-390.

WILF P. 2008. Insect-damaged fossil leaves record food web response to ancient climate change and extinction. New Phytol 178: 486-502.

WiLson KL AND Morrison DA. 2000. Systematics and evolution of monocots. Proceedings of the 2nd International Monocot Symposium. Melbourne: CSIRO.

WitTON MP. 2008. A new azhdarchoid pterosaur from the Crato Formation (Lower Cretaceous, Aptian?) of Brazil. Palaeontology 51(6): 1289-1300.

WU S-Q. 1999. A preliminary study of the Jehol flora from western Liaoning. Palaeoworld 11: 7-37. 